\title{
"I Identify Myself as Russian Although I Have Never Been to Russia": Ways of Transferring Identity and Language to Children among the Russian-Speaking Population of the USA
}

\author{
Tatyana Nikolaevna Yudina', Maria Grigorevna Kotovskaya², Maria \\ Vladimirovna Zolotukhina ${ }^{3} \&$ Dina Kabdullinovna Tananova ${ }^{4}$ \\ ${ }^{1}$ Russian State Social University, Moscow, Russia \\ ${ }^{2}$ Institute of Ethnology and anthropology, Russian Academy of Sciences, Moscow, Russia \\ ${ }^{3}$ National Research Nuclear University MEPhI and Russian State University named after \\ A.N. Kosygin, Moscow, Russia \\ ${ }^{4}$ Russian State Social University, Moscow, Russia
}

First published September 30, 2019

\begin{abstract}
:
The main goal of the paper is to analyze ideas and practices involved in the transmission of the Russian language and culture among members of Russian -speaking diaspora in the United States, mostly belonging to the two recent waves of immigration from the Soviet Union and Russia and residing in different parts of America. The bulk of academic publications for this paper were released in Russia with some from the US. Three methods were used: a questionnaire (8o questions, both open-ended and closed distributed via google form among middle-age and young members of the Russian -speaking community - 52 respondents), semi-structured interviews (a total of 20) and participant observation, primarily in Boston area and Ann Arbor, MI. When reflecting on affiliation with the Russian-speaking world the preservation of language and its transmission to future generations is viewed as the most important element of everyday life and aspiration for the Russian-speaking population regardless of their ethnic origin, religious beliefs, political preferences and social status. This attitude, perceived as critical for preserving cultural identity, appears to be true even for cases when such transmission did not prove to be successful.
\end{abstract}

Keywords: the Russian language, the Russian diaspora, community, identity, the Russian-speaking world, integration, assimilation, everyday practices, traditions.

\section{Introduction}

\section{Problem-based definition}

The reproduction of ethnocultural identity is a particular significant issue for immigrant communities: some of them form diaspora enclaves; others exist beyond clear boundaries and cannot be given specific definitions. immigrant communities are studied by scholars who prefer a narrower understanding of a diaspora (for example, "a network of public, cultural and educational institutions created by people from Russia and the United States of America in the $20^{\text {th }}$ and $21^{\text {st }}$ centuries to ensure support for the legal, sociocultural, professional and political adaptation of new migrants and the preservation of their ethnic traditions and customs") [Zatsepina, Ruchkin,

(c) AesthetixMS 2019. This Open Access article is published under a Creative Commons Attribution Non-Commercial 4.0 International License (http://creativecommons.org/licenses/by-nc/4.o/), which permits non-commercial re-use, distribution, and reproduction in any medium, provided the original work is properly cited. For citation use the DOI. For commercial re-use, please contact editor@rupkatha.com. 
2011: 290; Yudina, 2010) and those who write about the so-called diaspora behavior [Tishkov 2002, Gapova, 2004). This article addresses the issues of preserving the Russian language, teaching it and reproducing elements of ethnic identity in children either moving to a new country at a young age or born in the NEW country (of relocation). We suggest studying the "Russianspeaking America, community, diaspora or commune" as interchangeably designating people of the Soviet or Russian origin. The latter is recognized by them and manifests itself in mastering the Russian language (at different levels) and other practices. Such practices do not necessarily form social institutions although they remain united by a common idea of preserving elements of ethnic and cultural and transmitting them to their children.

The "identification of identity", i.e. the means of self-description and self-presentation as well as their significance among the representatives of a diaspora are not always directly related to the way identity is transmitted to the next generations. They often imply different combinations of aspirations and practices: ranging from purposeful and conscious actions aimed at preserving the language and culture and transfering this knowledge to children to situations where only some elements are transmitted (for example, gastronomic preferences). However, even a basic knowledge of any given language helps to maintain a certain level of identity and potentially encourage one's efforts to get acquainted with the history and culture of the country of origin and learn its language. This fact suggests a wide range of individual strategies and tactics in relation to the key components of identity, namely language.

The total number of people of the Soviet and Russian descent living in the United States is about three million (Belousova, 2012). Since the late $2 \mathrm{O}^{\text {th }}$ century, the number of Russian-speaking people has grown significantly and reached almost a million people, according to some estimates (Belousova, 2012). Exact calculations are complicated by the well-known fact that in English the terms "Russian" implying ethnicity and "Russian" implying nationality and Russian as a country (nation) are the same making it impossible for the English -speaking population to distinguish between the two. To make matters even more complicated quite often and the definition of "Russian" often implies the country of origin, i.e. it is no coincidence that representatives of the Jewish emigration jokingly talk about themselves: "well, finally, Jews became Russians".

There is no definitive idea about the exact number of the Soviet and Russian emigration waves to the United States of America, therefore, it is not always easy for immigrants to choose which wave they belong to (Semochkina, 2014: 78). Our research confirmed this tendency, especially among the younger generation. Considering the transmission of identity, As what concerns the transmission of ethnic and cultural identity the high-degree preservation of the Russian language and culture among descendants (up to today) is typical of post-revolutionary ("white") emigration. One of the factors explaining this peculiarity was that the members of the "white" emigres did not believe in the viability of the Bolshevik government. The next wave was formed by people displaced due to the Second World War. These communities (according to some estimates, their number reached 500,000 (Belousova, 2012)) were not characterized by active preservation of language and culture. The fate of the Jewish emigrants of the 1970s and the middle 1980 s varied. In any case, the issues of preserving the language among the representatives of this emigration wave were well-known., One of the researchers of the Russian culture of this period while writing for the San FrancisCo Russian Center newspaper traced many of these problems to the fact that the Russian children often did not learn to love the Motherland in their immigrant families: "If a child does not acquire

the Russian national spirit through hearing ((the)) Russian speech (in cross-cultural marriages) and does not develop even a basic understanding of the homeland of their father or mother... such a child quickly turns into a foreigner" (Antoshin, 2011: 4). For instance, the 
"Russkaya Zhizn" newspaper proposed to send emigrant children to the Russian Young Intelligence Organization to solve the problem.

Some scholars believe that the most numerous immigration of the late Soviet era and post-Soviet period continues to this day. It is parituclarly diverse in the social, ethnic and cultural sense and consists of several different groups - ((the)) refugees from the former Soviet republics, Jews, professionals (the so-called "brain drain"), those who won the green card lottery and, finally, those who go abroad to receive an educational degree and many others. The principal difference in the current situation from the previous ones is that anyone who has left Russia can return.

One of the key issues for the representatives of different emigration waves is not only the degree of their assimilation to a new culture or their personal success while mastering the different aspects of the new life (social, economic, etc.), but also a broad way of mastering a new way life. The latter suggests not the assimilation but rather integration with keeping the Russian language and preserving the culture not only for the current generation but also for their children.

In this regard, the questions to consider are the ways of determining one's identity and the degree of its importance; roots and origins; the concept of the homeland; the sense of belonging and boundaries between different types of communities; the identification main features of any given culture. All of the abovementioned suggests that it is the integration (rather than assimilation) that is the preferred strategy of adaptation in a new environment for emigrants and for children, leaving the questions about the motives and the methods of preserving the language and culture, as well as the corresponding problems. To be answered as well as the one about the problems that arise while undertaking this route.

\section{Methods}

From the methodological viewpoint, this article involves the analysis of the following sources:

- The results of participant observation, including the activity of emigrants from Russia (the USSR) on Facebook;

- The survey of people of different generations who lived or live in the United States and who traced their origin to the USSR and connected their identity with the USSR or Russia (52 respondents) conducted with the use of Google form between 2017 and 2019;

- Interviews with the representatives of the Russian-speaking community who have been living in the USA for 15-25 years.

Most respondents who agreed to participate in this study are women (40-55 years old ${ }^{1}$ ) with higher education (including American). The sampling is not representative and the respondents were selected using the snowball method. The respondents include professionals employed in educational institutions, system administrators, etc. According to the statements of many respondents, social characteristics are crucial for any given diaspora and manifest themselves in proficiency in the Russian language and its integrity.

\section{Results and interpretation}

\subsection{Identity in the USA and ethnic/national origins}

\footnotetext{
${ }^{1}$ One questionnaire was intended for people who have their own experience in raising children and transmitting culture and language, the other was aimed at people of younger age, grown up in the USA or even born there. Some senior respondents filled out a questionnaire oriented towards younger people or those who have not raised their own children yet.
} 
We should note that this research has confirmed earlier ideas discussed in similar studies (Zolotukhina, 2018; Ostroukh, Zolotukhina, 2016). There is no direct correlation between the original motives for moving to the United States and plans of those leaving Russia to preserve and use their mother tongue in the new place of residence. In our opinion, it is due to the fact that an unclear future is often associated with general low resources of the family and the tasks of preserving language and culture can hardly be viewed as a top priority: "Of course, I would have done everything in a different way. Back then we did not know whether how long we would stay - if at all" or "My sister simply had no time for that. The early 199os were a time of confusion. She worked a lot".

The way the adult immigrants evaluate their efforts to preserve the language and the culture of adult among themselves and their children is connected (though not directly) with identity awareness (reflection) which can be divided into ethnic, civil and the one related to the roots. The latter distinction is important as it allows to to separate one's origins and selfconsciousness. The survey answers were given in a free form and demonstrated a huge variety of options (some answers were provided in Russian but there were many written in English):

$\circ$ Russian-speaking Jew with Israeli roots living in the USA, having the Israeli and US citizenship;

- Russian with Jewish and Tatar roots;

- Russian-speaking (I would like to be a citizen of the world but my homeland is the Soviet Union); American of Russian-Jewish descent;

$\circ$ Jew/American/Russian Jew; Jew/American Israeli/Russian-Israeli;

$\circ$ Jewish woman from Russia who has been living in the USA most of her life; Russian/American/Russian-American;

- Jew/American/Russian and Jew/American/Russian (when the Russian means one's origin), etc.

The repsondents were particularly interested in reflecting on one's origins that cause a feeling of pride both among the first and the second generation of immigrants. Such topics are quite common for conversations with the locals especially if they hear an accent (it needs to be explained) with the local population who has an accent (it needs to be explained: "the reaction is usually positive but just to keep the conversation going"; "I speak English well but my accent is still very noticeable, so that people either ask where am I from or I explain it myself (for example, tell them about our traditions of meeting guests"). However, the awkward question of "where are you from or what do you consider your home?" may sound perplexing and be regarded as an act of microaggression or preexisting -knowledge that puts the respondent in a deliberately different, potentially stereotyped category of "others".

As we have expected when comparing the recent wave with the earlier ones a fundamentally new opportunity to return to the homeland allows representatives of the Russianspeaking population to view the move not as painfully as before when they "left forever and could not come back". Nowadays about half of the respondents regularly visit their historic homeland. At the same time this apparent accessibility of Russia and the Russian language can discourage them from maintaining their command of Russian.

Surprisingly such an important concept, as "motherland" did not cause an emotional response among the respondents: less than half of the respondents admitted that they missed their homeland and mentioned nostalgia. Seldom a topic of their discussion it is origins that presents the main element of their identity and the source of pride.

The key element of the "Russian-speaking world" (this denotation was chosen by the respondents instead of "Russian" or "Russia-based") and its distinguishing feature is language: 
"We are all different. We are united only by the language in which we think. Well, maybe there are also funny parties with music and dancing". If both spouses are Russian, they speak Russian at home and most of their friends are Russian-speaking. Both positive and negative values were mentioned as distinguishing features of the archetypical Americans and Russian-speakers . The Russian personality traits:

- Gloom and friendliness;

- Spiritual component - a more comprehensive view of humanity;

- Independence and satisfaction with their position in life;

- Less individualistic and more socially conservative (traditional) way of life, higher expectations from children;

- Close family ties and impudence;

- Americans take their own personal interests into account rather than the interests of their families (including parents, brothers and sisters);

- We pay more attention to education;

- We have a broader worldview;

○ Russians are interested in the opinions of other people;

- Orientation towards children upbringing rather than material well-being.

$\circ$ We pay more attention to education

We should mention that some answers to this question were given in English.

Many respondents consider their own "Russian-speaking world" as follows:

○ A group of people with whom I share experience, interests and worldviews;

- To communicate with people of common origins and similar views;

- Common childhood and adolescent memories, language and humor;

- Several people who help each other;

- A group or community of people united by common roots).

The respondents used different words to designate this Russian world, including "diaspora", "community", or "company of friends", in any case two-thirds of adult respondents consider themselves to be a part of the Russian-speaking community. In other words, there is a concept of "us" including:

- All native speakers of the Russian language and those who lived in the Soviet Union;

- Emigrants from countries of the former USSR united by the Russian language and common Russian culture;

$\circ$ People who speak the same language and share the unique experience of surviving in an alien cultural environment.

It should also be noted that the respondents did not comment on whether their stand on the matter was typical for the Russian speaking community.

The "unity of spirit" and mutual understanding are crucial in the process of communication due to the same language, a common cultural past, shared memories and similar experiences: "the opportunity to chat in a native language", "I communicate with people who share my views, interests and origins". At the same time, the respondents sometimes pointed to the certain artificiality or ephemeral nature of these personal connections: "the ability to speak your own language; common culture, concepts and traditions, even if they are only seeming. The possibility of being useful (for preserving this elusive culture)".

Interestingly, the Soviet model of a shared cultural past seems to be more positive: the Soviet elements (rather than modern Russian way of life) include "mutual assistance", "lending a shoulder", "a sense of responsibility for other children who are regarded as own offspring". The modern Russian way of life seems either less comprehensible or less attractive: "The Russian 
language simplifies communication. The Israeli experience brings together different worldviews. However, the main thing is that there should be interesting and friendly people, and it is always difficult to find such a group".

\subsection{The Russian language and children born in the USA}

In the context of raising children, the most important category is the language itself and the language "combined with" traditions (there were some answers excluding traditions). It is important to note that language is the most popular answer to the question of which ethnic traditions should be taken from parents and be kept by the younger generation. The issue of learning the Russian language and/or its preservation is fundamental for the absolute majority:

- The Russian language (like an ethnic tradition) and Jewish holidays;

- Rich Russian language;

$\circ$ Language of communication;

- Language and culture;

- Holidays, traditions, communication, the division of language into formal (for familiar teachers) and slang (for one's inner circle);

- Language, critical thinking, a fair share of cynicism;

- Acquaintance with the Russian way of life and conscientiousness (the study of these aspects based on "old" films, modern sitcoms and other TV shows (such as "Sklifosovsky") and literature - anything that can be "crammed" into.

The respondents highlighted the importance of providing access to the Russian cultural heritage. They noted that "the Russian language and culture are closely related to the world culture"; "it is necessary to preserve cultural roots"; "language is the most important part of the identity".

It is remarkable that language is mentioned together with faith, both Orthodox and Judaism: "the preservation of Orthodox spirituality; Jewish traditions and culture (literature, art, films, etc.)".

Although any language is an inherent value (the knowledge of an additional language, like any other knowledge, will never hurt), the preservation of the Russian language also has pragmatic aspects: "I do not want to lose it, it is good training for the brain; it will be included in my credit book" (i.e. will be useful in college). Sometimes teenagers become interested in language and begin to study it in college. For example, they call themselves "kheritazhniki" (from the word "heritage", denotes those who "inherited" the language of their parents) (Kagan, 2010). Consequently, the extinction of the Russian language from generation to generation is a nonlinear process.

One of the most difficult tasks is to motivate children to learn Russian and cultivate in them the idea that it is important to preserve their mother tongue:

- To be used within the family

- For communication with their parents and grandparents;

- Because I am their mother and I speak this language;

$\circ$ Being selfish in my suggestions, I would like to give them the Russian language as a memento;

- To have a common language with children which I know better than English, I want my children to know my favorite books, films, etc.;

- I need it since I cannot imagine communication with my children without something "ours", not everything cannot be conveyed in English (quotes from national movies, jokes and books). 
It is noteworthy that the respondents emotionally reacted to the question about the motives for preserving the language. We are talking about acquiring cultural competence allowing full-fledged communication.

The main difficulty in maintaining the language of children is associated with the disproportionate use of English in their life, especially if children go to school or preschool institutions: "the Russian language is not used in everyday life or communication with peers". Thus, there is a need to counteract the effect the US school. As a result, there is a reluctance to speak Russian because "English is easier". The problem is that the Russian language is not a part of the life of children and, therefore, is artificially maintained.

The above-mentioned facts stipulate the task of parents: "to teach their children how to read before they go to school; create and maintain the circle of the Russian communication with peers as long as possible, spend more time with children, watch movies together (on the Internet) and, especially, listen to audio tales from the GosTeleRadio Fund. Never scold them in Russian or any other language to establish a trusting relationship".

Therefore, it is necessary to "teach children to love the native culture of their parents so that they would like to read and see what their parents read". In addition to the importance of communication, reading is mentioned as "the main skill that needs to be learned. However, it is very difficult as in the process of learning children need the systematic approach and practice. It is important to maintain their vocabulary and expand their active word stock at the level of Russian-speaking peers".

\subsection{Ways of preserving the Russian language by emigrants from Russia}

There are many effective ways of maintaining language mentioned by the respondents, including "informal communication", "conversations with peers"; "the Russian school, trips to Russia, summer camps". Theatrical performances, membership clubs and other activities improve the child's spontaneous speech because children find themselves in the Russian language environment and listen to adults who will not switch to English. Thus, children see the functional application of language - for instance, how a play is presented in the language which is being learned (Russian).

Over half of the respondents believe that the efforts solely by the family are enough to preserve the Russian language. The others are convinced that "outside help is much more effective". One woman explained, "I think it is possible to maintain the Russian language only at the family level, but I myself studied with a Russian teacher for about eight years". However, it does not mean that people do not try or give up trying to preserve their native language individually: "we do not go anywhere, we just do it ourselves. Yes, it is less effective, but there is nothing to do with that". According to our survey, more than $50 \%$ of the respondents' children do not attend the Russian-speaking school ${ }^{2}$; in the next age cohort (teenagers and young people) more than $75 \%$ attended it: "parents sent me there and I attended these classes. It was interesting there and my dear mommy was happy".

The respondents themselves try to speak Russian within their family and with Russianspeaking friends. It comes as no surprise that most of them regard Russian as their first language but express this idea in different ways. However, not everyone uses the Russian language in their everyday life or simply does not succeed in it. The reason is a growing frustration due to

\footnotetext{
${ }^{2}$ As a rule, Saturday or Sunday schools that function either under religious institutions or partially sponsored by local authorities - for example, some premises may be provided on preferential terms.
} 
misunderstanding: "it is faster and more convenient, that is the way of the world". During communication children respond differently, but there were answers: "only in Russian". Many young respondents not only said that they spoke Russian at home but also claimed that they responded to their parents in Russian. While communicating with their peers, children often speak English but sometimes "it depends on the situation".

According to the informants, Russian persistence is a driving force behind this phenomenon of language preservation. And, certainly, relatives play their role: "I identify myself as Russian, although I have never been to Russia. I just look at the world in a different way, unlike the Americans. No wonder, I have been eating my grandmother's soup for so many years. I didn't English until I was eight".

Indeed, everyday practices accompanying language also play a crucial role. Many of them are supported not only by parents but also by the older generation (when it comes to multigenerational emigration): when we get together with grandparents we mostly cook Russian dishes; my mother makes pies, quark pancakes, cottage cheese, dumplings, pancakes; the first course; we love Russian pickles (salted cucumbers) and sauerkraut". The list can be completed by the following products: "chocolate glazed curd bars", "ptichye moloko" (soft chocolate-covered candy filled with marshmallow), "kefir" (traditional fermented dairy) and "dumplings".

Traditions are preserved in the approach to feeding arrangement: sausage or cheese sandwiches for breakfast; hot soups for lunch (American children do not usually eat soups).

According to the repsondents, collective meals are important as a way to spend quality time together with one's family and an opportunity to maintain traditions, not necessarily the Soviet-Russian ones. It can be Thanksgiving, Christmas (not so much as a religious holiday but a family dinner and reunion because everyone has a day-off), New Year, family birthdays... Meals shared over one table and songs with dances are the most important components of any holiday like the Russian salad for New Year; feasts with a huge amount of home-cooked food (Americans do not cook at home, they usually meet in a restaurant or go for a picnic to a park). The most typical statements are as follows:

- Meet twice a year and celebrate the Passover and the Jewish New Year in Russian;

- Old New Year, Shrovetide, the Russian Festival (in the fall at churches);

- Holidays of the Soviet era: New Year and Christmas tree; the Russian salad;

○ March 8, May 9;

- We go to a bathhouse on the night of New Year.

The key motivating factor for adults is the desire to engage children in celebrating these holidays: costumed children's matinees with the Snow Maiden and Jack Frost (it is convenient that children have costumes that remain after Halloween, but parents often prefer to reproduce the style known from childhood). The format of holidays reminds typical Soviet events but they are often held at the church. There are also many activities outside churches that are common for children and adults, including New Year carnivals held in specially rented premises, etc. Particular attention should be paid to the celebration of Victory Day. In the USA, the day of surrender is May 8 and little information is presented about Victory Day in the existing school program.

Therefore, the transmission of values and language cannot but experience the influence of such a unifying feature of the Russian-speaking community as an attitude towards children and upbringing: "children are the center of the Universe"; "children are to be taught". "As a rule, Russian parents are very demanding on their children in terms of manners, upbringing and education (they monitor progress and require good grades), as well as respect for elders. Americans are calmer in relation to their children and "try not to ruin their childhood". This approach can have positive results and lead to "rejection" in some cases. A 21-year-old respondent 
born in the USA emphasized "imposing parents' views and tastes on their children; tell them what to do".

The above-mentioned facts do not mean that there are no problems hindering communication and collective solution of the problems relating to the transmission of culture and language. These problems include different levels of culture, its primitiveness and inflated requirements: "the longer you live in the country and the better you adapt to its conditions, the less you need to communicate only with people of common origin". After all, they are completely different people united not by common interests or socio-economic factors but by language environment; they inevitably become frustrated and end up in conflict situations.

\section{Discussion}

In our opinion, the clear division of the Russian and Russian-speaking community made by other scholars is simplification or schematization (Ruchkin, 2016). Unlike other large ethnic groups living in the USA, the Russian-speaking diaspora community "...is not organized and does not have political power... but can be formed as a network where horizontal links prevail over vertical ones" (Kalinkin, 2011: 11). Of course, a special role in maintaining any kind of connections is played by the language, including the desire to pass on language knowledge to children.

In this connection, it is relevant to mention I.V. Pustovoit's conclusion that "...the undulating and ethnically or religiously heterogeneous nature of emigration does not allow to present the development of the Russian language in the United States in the form of a continuum. Thus, the last wave of the post-Soviet emigration has created the Babylonian mixture of cultures, languages and customs of the most diverse ethnic groups, which are still perceived as a unified Russian diaspora from the outside. Like the American one, this Russian "melting pot" upon closer inspection appears as a "salad" consisting of numerous ethnic and regional ingredients. Despite complex processes of national identity in the conditions of emigration, the Russian language serves as the only unifying factor" (Pustovoit, 2015: 166.)

It is suggested that language connects but does not unite different layers (Ruchkin, 2016). In any case, it survives although there is very little institutional and no national support of the Russian language. However, language schools can be supported by local authorities (for example, finding a suitable facility, tax breaks). As we can see, an internal request for preserving the Russian language and its transmission exists and is implemented in various forms: completely conscious or not subjected to reflection. People present ideas about their origin in different ways, including information about family roots, impressions of communicating with "theirs" (diaspora representatives), with whom they share common experience and common past, a single or comparable linguistic and cultural code, including holidays and rituals, and sometimes even purposeful efforts to acquaint children with their mother tongue or maintain the existing language knowledge. The latter is especially typical of those actively involved in each other's life: adaptation as a whole; emergencies; job application; solving domestic issues; seeking help at home. Help in domestic matters is simple and accessible if neighbors know when "they can come to borrow some salt" (and whether it is possible). Actually, one of the reasons for communication is the creation or maintenance of the preferable language environment.

Sometimes this version of Russian differs from its "literary" form and is used by people who have just crossed the international border. It is the Americanized Russian language "Runglish" (Naidenova 2010). It retained the Russian grammar but borrowed many lexemes from American English. For instance, "Сдаю тубедрумный апартамент" ("I rent out a two-bedroom apartment") (Burvikova, 2012), "послайсьте мне хлеб, пожалуйста" ("slice the bread for me, 
please") or "зачем тебе брать этот автобус" ("why do you take this bus?"). Nevertheless, there are many examples when the richness and purity of the Russian language not only remain and develop in relation to the Russian emigrants but also are also successfully transferred to children.

Regardless of homesickness or active plans to return home present in the respondents' worldview, they clearly want to preserve their culture and language - the latter being the crucial factor vital for keeping the culture and listed by more than $90 \%$ of the respondents.

This value also characterizes cases not related to the actual membership in some diaspora or immigrant community. In any case, communication, collective or shared practices, as well as mutual assistance in different situations are important components of everyday life among the Russian-speaking residents of the United States even if they do not consider their ties with the Russian-speaking world to be very intense.

Literature turns out to be the most valuable asset that can be "taken" from this world: it gives an opportunity to understand the "other side". The list of such assets can be filled with history, culture and Orthodoxy. The latter is the most important factor in learning the language and attending the Russian school for many emigrants. Such expansion of one's worldview helps to develop a non-American-centered model of the world, preserve cultural roots and finally acquire new knowledge, including knowledge of the parents' culture and traditions.

Most respondents noted that they knew successful examples of mastering the Russian language. However, they clearly understand that their children can acquire only some elements of their culture. The fact that it is possible motivates many people: "I know people in the second and third generation who have preserved their mother tongue". We seldom experience the feeling that representatives of the first generation completely forgot their native culture and language, but it can be a common case for the second and subsequent generations living in the Russian-speaking environment. In addition, individual reasons can be determinative: "the eldest son (16 years old) is self-interested, he chose Russian as one of his school subjects; the youngest (10 years old) does not want to study Russian at all". At the same time, more than half of the respondents (both those who teach their children and students the Russian language and culture) are satisfied with their efforts in the field of language preservation: "being adults now, they like it"; "I hope that they do not criticize us for that and are thankful"; "my daughter is glad that she can freely speak, read and write in the Russian language (almost without any mistakes). When I studied French, I was pleasantly surprised (with borrowed words) that I already knew from Russian".

It is expected that integration into a new environment combined with the maintenance of multiple identities should be seen as the preferred scenario for both adults and children, according to most respondents. The respondents noted that they did not experience coercion to assimilate. Some of the adolescents and teenagers consider themselves "Jewish Americans of the Russian descent" or "more or less Russian but at the same time American". Of course, linguistic and cultural competences are necessary for this integration scenario. Such values and orientations are "inherited".

\section{Conclusion}

The preservation of language and its transfer to future generations is the most important element of everyday life and aspiration for the Russian-speaking population of the USA regardless of their origin, religious beliefs, political affiliation, etc. Thus, we can highlight the inherent value of language and the great importance of culture, as well as a fixation well as the hope and aspiration to integrate and not assimilate. When it is proved to be impossible to transfer the language from one generation to another or seems to be diificult to acheve it at present it is easy to sense the regret or disappointment on the face of respondents among the respondents trying to find some 
explanation or justification. Indeed, preserving a language is easier than learning a new one. However, these efforts require an enormous amount of resources (both personal and public) coming from the diaspora community in any form. The reward for many-year work will be the understanding of people, history and culture of Russia at their best, as well as the importance of family ties, the ability to think independently, different interests, love to reading and finally the awareness of the diversity of all peoples and cultures. Therefore, we can look into the future optimistically and assume the development of complex, mosaic and complementary cultures, i.e. the Russians always hope for the best.

\section{References}

Antoshin, A.V. Kultura Rossiiskoi diaspory v SShA (1960-1980) [The culture of the Russian diaspora community in the USA (1960-1980)] // Oikumena Regionovedcheskie issledovaniya 2011. 1. P. 1-11.

Burvikova, E. Russkii yazyk v Novoi Anglii: opyt prepodavaniya RKI v universitetakh [The Russian language in New England: teaching Russian as a foreign language in universities] // Russkii yazyk za rubezhom. 2012. 1(23). P. 116-120.

Gapova, E. Zheny russkikh programmistov, ili Zhenshchiny, kotorye edut vsled za muzhchinami [Wives of Russian software developers, or the women who follow their men] // Semeinye uzy: modeli dlya sborki: compiled and edited by S. Ushakin. Moscow. 2004. P. 409-431.

Zatsepina, O.S., Ruchkin, A.E. Russkie v Amerike: Obshchestvennye organizatsii russkoi emigratsii v XXXXI veke [The Russians in America: non-governmental organizations of the Russian emigration in the $20^{\text {th }}$ and $21^{\text {st }}$ centuries]. RACH, 2011.

Zolotukhina, M.V. Russkoyazychnaya Amerika: identichnost i obraz zhizni [The Russian-speaking America: identity and way of life] / Russkii mir v menyayushchemsya mire / Editor-in-chief: G.A. Komarova. Moscow: IEA RAN. 2018. P. 129-146 (chapter 10 in a multi-authored monograph).

Kalinkin, V.Yu. Osobennosti politicheskoi deyatelnosti russkoyazychnoi diaspory v SShA [ Political activities of the Russian diaspora community in the USA]. Moscow, MGU. 2011.

Naidenova, N. Runglish. Saint Petersburg, 2010.

Ostroukh, I.G., Zolotukhina, M.V. Za predelami Rossii [Beyond the borders of Russia] / Briks, 2016. 3(14).

Pustovoit, I.V. Na perekrestke dvukh mirovykh yazykov: russkoyazychnaya diaspora SShA [At the crossroad of two global languages: the Russian-speaking diaspora community in the USA] // Russkii yazyk i literatura v prostranstve mirovoi kultury. Proceedings of the $13^{\text {th }}$ Congress MAPRYaL in 15 volumes. 2015. P. 166-170.

Ruchkin, A.B. Russkaya diaspora v SShA: reaktsiya obshchestvennykh organizatsii na sobytiya na Ukraine i prisoedinenie Kryma [The Russian diaspora in the USA: the reaction of non-governmental organizations to Ukrainian events and the annexation of Crimea]. Znanie/ponimanie/umenie, 2016. 1. P. 201-215.

Semochkina, E.I. Volny rossiiskoi emigratsii kak istoriograficheskaya problema sovremennogo otechestvennogo emigrantovedeniya [Waves of the Russian emigration as the historiographical problem of modern Russian emigration studies] // Vestnik Omskogo universiteta. Seriya "Istoricheskie nauki" 2014. 1. P. 78.

Tishkov, V.A. Istoricheskii fenomen diaspory [The historical phenomenon of diaspora] // Etnologicheskoe obozrenie. 2002. 2.

Yudina, T.N. Teoriya i metodologiya etnosotsialnogo issledovaniya [The theory and methodology of ethnosocial studies] // Sotsialnaya politika i sotsiologiya. 2010. 1(55). P. 273-291. 
Belousova, M. The Russian Diaspora in the US // Russian Analytical Digest. No. 107. January 27 2012. URL: http://www.laender-analysen.de/russland/rad/pdf/Russian_Analytical_Digest_107.pdf

Kagan, O. Russian Heritage Speakers in the US: A profile // Russian Language Journal. Volume 6o. 2010. P. 21-228. URL: http://www.jstor.org/stable/43669184 